\title{
Hledání Nové Evropy v textech T. G. Masaryka \\ a Romana Dmowského. Komparativní pohled
}

\section{The search for New Europe in texts of Tomáš Garrigue Masaryk and Roman Dmowski: a comparative perspective}

Milan Scholz / misch12@centrum.cz

Seminář obecných a komparativních dějin, Filozofická fakulta, Univerzita Karlova, CZ

\begin{abstract}
This article provides a comparative analysis of the search for a New Europe in the texts of Tomáš Garrigue Masaryk (1850-1937) and Roman Dmowski (1864-1939). Both Masaryk and Dmowski were prominent representatives of the public and political life in their countries at the end of the $19^{\text {th }}$ and in first decades of the $20^{\text {th }}$ centuries. During the First World War they became the leaders of Czechoslovak and Polish politics in West European exile. Their objectives consisted in the (re-)establishment of independent Czechoslovak and Polish states.
\end{abstract}

\section{Keywords}

Tomáš Garrigue Masaryk, Roman Dmowski, New Europe, comparative history of ideas, historical examples, mental geography 


\section{Úvod}

Tomáš Garrigue Masaryk (1850-1937) a Roman Dmowski (1864-1939) náleželi bezesporu k čelným představitelům veřejného a politického života svých zemí na přelomu 19. a 20. století a v prvních desetiletích 20. století. Před rokem 1914 Masaryk a Dmowski ovlivnili českou a polskou politiku a politické myšlení. Během první světové války se postavili do čela československé a polské emigrační politiky (Masaryk jako předseda Československého národního výboru, Dmowski jako předseda Polského národního výboru). V poválečném období se však jejich životní dráha rozcházela. Masaryk se stal prezidentem Československa a symbolem československé identity, Dmowski reprezentoval spíše opozici vưči hlavnímu proudu polského poválečného politického života. Hledání Nové Evropy patří k tématům, jež byla paralelně zachycena v Masarykových i Dmowského textech a představuje proto téma nanejvýš vhodné pro komparativní výzkum. Př́spěvek se zabývá otázkou, jakou pozici na mapě Evropy Masaryk a Dmowski svým zemím přikládali, jak odpovídali na otázku „kam patříme“ a jak svá stanoviska argumentačně podkládali.

\section{Masarykova a Dmowského činnost před první světovou válkou: pokus o srovnání osobností}

Tomáš Garrigue Masaryk narozený roku 1850 vstoupil na veřejnou scénu v chronologickém ohledu dříve než o čtrnáct let mladší Roman Dmowski a jako univerzitní filosof a společensky angažovaný akademik s přesahem k erudované publicistice se stal výrazným zjevem českého intelektuálního života již brzy po svém př́íchodu do Prahy roku 1882. Roman Dmowski se na počátku své životní dráhy po dokončení univerzitních studií přírodních věd se specializací na biologii rozhodoval mezi akademickou kariérou na univerzitě a veřejným (politickým) působením s těžištěm v oblasti národně-osvětové a publikační činnosti. Ačkoliv univerzitní učitelé Dmowského přemlouvali k volbě akademické dráhy, rozhodnutí plně se věnovat politické a publicistické práci padlo u Dmowského brzy, záhy po ukončení univerzitních studií roku 1891, a bylo umocněno a z materiálního hlediska umožněno zhodnocením dědictví po otci. Dmowski pocházel z relativně chudých poměrů, jeho otec však svého času zakoupil tehdy málo hodnotné pozemky blízko svého bydliště na okraji Varšavy, které nabývaly v souvislosti s růstem města na ceně. To Dmowskému umožnilo nezávislou existenci.

V období před první světovou válkou Masaryk i Dmowski významně zasáhli do uvažování o národní identitě svých národů, podrobovali kritice dosavadní národní politiku a pokoušeli se hledat cesty, jak reformulovat národní program takovým způsobem, aby byl v nadnárodním kontextu životaschopný. V případě Masaryka v tomto ohledu sehrály klíčovou úlohu texty k české otázce z 90. let 19. století reprezentované zvláště publikacemi Česká otázka (1894), Naše nynějši krize (1895) a Jan Hus (1896). ${ }^{1}$ Další Masarykovy

1 Otto Urban hodnotil právě tyto tři Masarykovy tituly jako centrum Masarykova pojetí filosofie národní existence. Srov. Urban, Otto: Masarykova česká filosofie. Československý časopis historický 1969, s. 539-544; týž: Česká společnost 1848-1918. Praha 1982, s. 440. 
práce z 90. let dotýkající se české otázky, obsáhlá studie Karel Havliček (1896) i menší práce Palackého idea národu českého, Masarykovo základní schéma doplňovaly. Tyto texty se při celkově kritickém pohledu na dosavadní pojímání národních úkolů a dobové národní politiky pokusily nabídnout novou, životaschopnou perspektivu pro národní identitu, založenou podle Masarykových představ na realistickém základě kontrastujícím s východiskem bájným a vybájeným, charakteristickým pro Rukopisy. Dmowski se stal profilovým reprezentantem polského politického myšlení a uvažování o polské národní identitě na počátku 20. století, zvláště po publikování práce Myśli nowoczesnego Polaka roku 1903, založené na historické perspektivě a historické argumentaci. Text se vyznačoval hluboce kritickým př́stupem k polskému historickému vývoji i polskému národnímu hnutí. Dmowski si otevřeně kladl za cíl pojmenovat a analyzovat národní chyby a přispět tak k jejich nápravě. Své pojetí národního programu a historicky zargumentovaný pohled na geopolitické postavení Polska Dmowski (kromě drobnějších textů) před první světovou válkou dále rozvinul v pracích Niemcy, Rosja i kwestja polska (1908) a Upadek myśli konserwatywnej v Polsce (1914).

Vedle př́íspěvku k myšlení o národní identitě a k politickému myšlení Masaryk i Dmowski v období před první světovou válkou činně zasáhli do národní politiky svých zemí. Masaryk vykonával v letech 1891-1893 funkci rakouského říšského i českého zemského poslance za mladočeskou stranu, po roztržce s hlavním stranickým proudem se však funkce vzdal. Od roku 1900 rozvíjel politickou činnost v rámci své vlastní, tzv. realistické strany, kterou v letech 1907-1914 zastupoval ve vídeňském řrisském parlamentu. Roman Dmowski, pocházející z ruského záboru Polska a pobývající mezi lety 1895 a 1905 v emigraci v rakouském záboru, se stával na přelomu 19. a 20. století klíčovou postavou národně demokratického proudu, který představoval zvláště v ruském záboru vedle socialistického směru hlavnî politickou linii moderní polské politiky. Po revoluci roku 1905, po níž byly v carské ŕišsi položeny základy moderního parlamentarismu, získal Dmowski roku 1907 post poslance Dumy, kde byl zvolen předsedou jednotného polského poslaneckého klubu a stal se záhy nejznáměǰším polským politikem. Ačkoliv se Dmowski poslaneckého mandátu z taktických důvodů roku 1909 vzdal a v národně demokratické straně došlo v následujících letech $\mathrm{k}$ několika rozkolům ohledně směřování strany, byl Dmowski po publikování práce Niemcy, Rosja $i$ kwestja polska roku 1908 (přeložené do francouzštiny, ruštiny a finštiny) nezřŕdka označován za „ministra zahraničí“ dosud neexistujícího polského státu.

V politické oblasti Masaryka a Dmowského od počátku veřejné působnosti spojovalo úsilí o národně osvětovou činnost a důraz na „drobnou práci“, která se měla stát základem politiky. V Masarykově i v Dmowského myšlení se přitom výrazně uplatňoval akcent kladený na dlouhodobost jakéhokoliv programu. Ačkoliv Masaryk i Dmowski svého času zastávali post poslance, parlamentní politiku jako tzv. politiku dne oba pokládali v kontrastu k preferované politice dlouhodobosti (jejíž podstatnou součástí bylo uvědomělé hledání národní identity) pouze za druhotné, odvozené pole své působnosti. ${ }^{2}$ Masaryk i Dmowski silně zdůrazňovali nutnost trpělivosti v politice, význam idejí a ideálů.

2 Srov. hodnocení Dmowského spolupracovníka Władyslawa Jabłonowského (1865-1956), který tvrdil, že Dmowski je „duchem stálosti a dlouhodobosti“. Jabłonowski, Władyslaw: $Z$ biegiem lat. Wspomnienia o Romanie Dmowskim. Częstochowa 1939, s. 61. 
Ve srovnání s Masarykem spočívala Dmowského veřejná činnost od počátku výrazněji v oblasti politiky, politiku však Dmowski vnímal v první řadě jako prostředek formování národního smýšlení. Profesor krakovské univerzity historik Władysław Konopczyński (1880-1952) řadil Dmowského především do kategorie „lidí pera, slov a činu, šermírú ideje vlasti“" a klasifikoval jej jako jednoho z předních polských politických myslitelů, který uměl lépe než jiní spojovat pisatelskou a publicistikou činnost s politickou prací. Dmowski se podle jeho názoru stal reprezentantem třetí cesty mezi povstaleckou taktikou a loajalismem založené na každodenní osvětově-politické práci. Národně demokratický politik a publicista Zygmunt Wasilewski (1865-1948) Dmowského podobně popsal jako člověka, který nebyl politickým hráčem, ale „národním tvůrcem“, člověkem vytvářejícím politiku samu. Podle Dmowského přítele, historika Franciszka Bujaka (1875-1953), představoval Dmowski osobnost, která žila z pisatelské práce, a to „bez teatrálních gest a jarmareční reklamy. “3 Podle hodnocení Dmowského životopisce Romana Wapińského měla předválečná polská národně demokratická politika (jejímž čelným představitelem Dmowski byl) mnoho společného s tzv. „reálnou politikou“ (etapovou politikou) představující hlavní proud dobové české politické kultury. ${ }^{4}$

Masaryk a Dmowski představovali svým světonázorovým založením od počátku rozdílné osobnosti. Masarykův kontinuálně humanistický akcent kontrastoval s Dmowského otevřeně deklarovaným důrazem na národ a národní zájem. V Dmowského myšlení byly navíc po celý život latentně přítomny antisemitsky laděné prvky (které se výrazně prohloubily v období po první světové válce), což byl jev, který Masarykovo a Dmowského uvažování vzájemně vzdaloval asi nejvýrazněji. Dmowského biologizující pojímání dějin ovlivněné darwinismem (a zvláště sociálním darwinismem) bylo značně vzdálené Masarykovu způsobu uvažování, odmítajícímu darwinistické impulsy jako módní (a podle Masaryka nedomyšlené), avšak nemoderní koncepty. ${ }^{5} \mathrm{Na}$ druhé straně je nutno zdůraznit, že tento rozdíl mezi Masarykovým a Dmowského př́stupem se daleko výrazněji dotýkal dějin společnosti, vývoje kolektivů, než pohledu na problematiku lidského jedince a jeho místa v dějinném procesu. V Dmowského myšlení byla totiž přítomna zvláštní dichotomie - Dmowského pohled na vývoj společnosti byl ovlivněn darwinistickými teoriemi o boji o život, Dmowského nazírání na problematiku jedince však vycházelo z křestanské morálky a Dmowski v tomto ohledu soutěživost a soupeření jako základ vývoje odmítal. Darwinistický „boj“ představoval pro Dmowského soutěžení mezi státy a národy, nikoliv soutěžení v mezilidských vztazích. ${ }^{6}$

3 Jedná se o postoje k významu Dmowského osobnosti vyslovené u př́ležitosti Dmowského úmrtí na počátku roku 1939. Konopczyński, Władysław: O miejsce dla Dmowskiego v historii; Wasilewski, Zygmunt: Twórca $i$ wtadca dusz w narodzie; Bujak, Franciszek: Gtos Franciszka Bujaka. Přetiskuje Wolikowska, Izabella: Roman Dmowski. Człowiek, Polak, przyjaciel. Wrocław 2007, s. 231-232, 234, 239.

4 Wapiński, Roman: Roman Dmowski. Lublin 1988, s. 156.

5 Na protikladnost Masarykova a Dmowského světonázoru sumarizujícím způsobem poukázal Latawski, Paul: The Discrepancy between State and Ethnographic Frontiers. Dmowski and Masaryk on Self-determination. In: T. G. Masaryk (1850-1937). Sv. III. Statesman and Cultural Force. Ed. H. Hanak. London 1990, s. 86. Latawski přitom konstatoval, že Masarykova a Dmowského stanoviska se vzájemně shodovala zejména v jedné podstatné otázce, totiž v otázce národního sebeurčení.

6 Dmowski, Roman: Myśli nowoczesnego Polaka. Komorów 2011 [1903], s. 75-76. K interpretaci srov. Wolikowska, I.: Roman Dmowski, s. 247. 


\section{Masaryk, Dmowski a první světová válka}

Po propuknutí první světové války se Masaryk i Dmowski stali reprezentanty úsilí o vydobytí nezávislosti svých zemí a oba odešli do západní emigrace, odkud se pokoušeli řídit a koordinovat národní politiku. Oba během války vypracovali geopoliticky a historicky zargumentované projekty nové (střední) Evropy, v nichž v kontextu silokřivek evropského vývoje hledali místo pro nezávislou existenci svého národa a zdůvodňovali nutnost, proč je samostatnost Československa a Polska nezbytným prvkem nové politické geografie Evropy, významným nejen pro střední Evropu, ale i pro Evropu jako celek. ${ }^{7}$

V období první světové války docházelo mezi Masarykem a Dmowským k pracovním kontaktům. Masaryk a Dmowski se jako reprezentanti československého a polského zahraničního odboje sešli několikrát v průběhu roku 1916 v Londýně. První schůzka se konala 18. března, kdy o vzájemné setkání požádal Dmowski. Dmowski, který na rozdíl od Masaryka tehdy sídlil v Paříži, byl na Masaryka odkázán ruským velvyslancem ve Francii Izvolským a ruským žurnalistou Svatkovským. Dmowski při setkání Masarykovi sdělil, že jej Izvolskij při vzájemném rozhovoru upozornil na velkou shodnost mezi Dmowského a Masarykovými názory na budoucí uspořádání Evropy po první světové válce. Od Izvolského byl Dmowski o Masarykovi dobře informován a referoval, že také britský předseda vlády Asquith je zaujat Masarykovými argumenty. Dmowski Masaryka ujistil, že rozbití Rakouska-Uherska je v polském zájmu. Znovu se Masaryk s Dmowským setkal 24. března 1916. Dmowski se mezitím z dokumentů, které mu Masaryk předal, seznámil s Masarykem formulovanou představou budoucí Evropy a dospěl k závěru, že československá a polská idea budoucnosti střední Evropy jsou shodné. Masaryk se při obou schůzkách snažil o koordinaci československého a polského postupu a pokoušel se Dmowského přemluvit, aby odcestoval do Petrohradu a podílel se na organizaci odboje proti Ústředním mocnostem v Rusku. Dmowski však tuto alternativu odmítl, protože v ní spatřoval nebezpečí, že by byl ruskou stranou zadržen a nemohl se již do západní Evropy vrátit. K dalšímu setkání mezi Masarykem a Dmowským došlo 18. června 1916. Dmowski tehdy vyjádřil myšlenku, že v budoucnosti by mohl vzniknout polsko-český (československý) stát. Masaryk touto myšlenkou nebyl překvapen, nebot se s ní setkal již dříve, jeho vlastní stanovisko bylo však zdrženlivé. ${ }^{8}$ Podle vzpomínek Hipolita Korwina-Milewského (1848-1932) Dmowski již v březnu 1916 prosazoval myšlenku vzniku nezávislého českého státu existujícího vedle nezávislého Polska, přičemž předpokládal, že ve vzájemném vztahu budoucích dvou států by mělo Polsko díky daleko většímu počtu obyvatelstva i díky bohatší historii nezávislé státnosti převahu a vykonávalo by nad českým státem cosi na zpo̊sob „morálního a kulturního protektorátu“. Zároveň ale Dmowski uznával,

7 O srovnání se pokusil již Janoušek, Emauel: Masarykova Nová Evropa a Dmowského Problems of Central and Eastern Europe. Slovanský přehled XXII, 1930, s. 86-98.

8 O schůzkách pojednává Polák, Stanislav: T. G. Masaryk. Za ideálem a pravdou V. Praha 2009, s. 122-123, 148, který čerpá ze záznamů o schůzkách z A-ÚTGM, Masarykovy deníkové záznamy, nadpis Dmowski, 8 , 18., 24. 3., 18. 6. 1916, dopis Dmowski - Masaryk, 24. 3. 1916; Žáček, Václav a kol.: Češi a Poláci v minulosti II. Období kapitalismu a imperialismu. Praha 1967, s. 382, 385-386, 388. O rozhovorech s Dmowským se Masaryk bez časového vymezení zmiňoval ve svých vzpomínkách, Masaryk, Tomáš G.: Světová revoluce. Praha 1925, s. 137, 295-296. 
že české země byly hospodářsky pokročilejší a domníval se, že podnikavé české etnikum by mohlo být ekonomicky činné i v Polsku, kde by vyvažovalo či dokonce nahrazovalo ekonomicky dominantní židovskou komunitu. V letech 1917-1918 Dmowski podle Korwina-Milewského českým politikům navrhoval vznik polsko-československé federace, nenalezl však na české straně odezvu - zvláště Edvard Beneš se obával př́lišné polské převahy v československo-polském svazku, což přispívalo k rostoucímu napětí mezi oběma politiky. ${ }^{9}$

O svých válečných rozhovorech s Dmowským podal Masaryk informace ve zprávě ministerské radě 28. prosince 1918. Dmowski podle Masarykova svědectví ve Spojených státech amerických na podzim 1918 Masarykovi jménem Poláků navrhoval utvoření československo-polské federace a Masaryk tehdy návrh odmítl s tím, že Polsko samo o sobě bude mít po válce „velké úkoly“, od kterých by ho federace mohla zdržovat. Eufemisticky tím Masaryk naznačil svůj předpoklad, že poválečný vývoj Polska bude problematický a snad i neuspořádaný. Dmowski podle Masaryka tento názor přijal a rozvinul dále teze o možnosti vzniku nějaké hospodářské unie či defenzivního vojenského společenství. Řeč se stočila i na otázku sporných hranic ve Slezsku (Těšínsko), ${ }^{10}$ Masaryk Dmowského vybídl, aby vypracoval návrh dohody, prostřednictvím níž by Čechoslováci a Poláci ukázali před zrakem Dohody na vzájemnou svornost a rozptýlili tak obavy z vývoje v nových poválečných státech. ${ }^{11}$

Souhra okolností a zvláště rozdílnost českého (československého) a polského odboje i rozdílnost situace na domácí scéně přispěly k tomu, že se Masaryk, řídící Československý národní výbor, stal v zásadě všeobecně uznávanou autoritou a mluvčím československých aspirací na národní nezávislost, zatímco Polský národní výbor (Komitet Narodowy Polski) pod vedením Romana Dmowského zůstal sice prvním (a v očích Dohody nejuznávanějším), avšak přesto jen jedním z konkurujících si uskupení. Na konci války převzal na polské domácí scéně výraznou iniciativu domácí odboj, do jehož čela se postavil představitel polských socialistů, charizmatický vojevůdce Józef Piłsudski (1867-1935), a Dmowského linie se na přelomu let 1918 a 1919 dostala na vedlejšŕ kolej. Do hry záhy vstoupil třetí hráč, světoznámý virtuóz a hudební skladatel Ignacy Paderewski (1860-1941), dosavadní člen Dmowským řízeného Polského národního výboru, který ve výboru ztělesňoval od počátku určitou opozici vůči Dmowského vedení. Paderewski začal kooperovat s Piłsudským a stal se v lednu 1919 nadstranickým předsedou vlády s potenciálem spojovat znesvářené politické tábory. Když se Paderewski jako polský premiér v dubnu 1919 ujal vedení polské delegace na versailleské konferenci, Dmowski se stal až druhým polským delegátem na mírových rokováních.

9 Korwin-Milewski, Hipolit: Siedemdziesiąt lat wspomnień (1855-1925). Poznań 1930, s. 435.

10 Komplikované otázce Těšínska se zde nelze blíže věnovat. Blíže srov. např. Valenta, Jaroslav: Česko-polské vztahy v letech 1918-1920 a Těšinské Slezsko. Ostrava 1961.

11 Zpráva existuje ve dvou verzích, 1) Masaryk, T. G.: Zpráva ministerské radě o zahraniční činnosti. Masaryk, Tomáš G.: Cesta demokracie I. Praha 2003, s. 50, 51, přetisk podle stenografického záznamu řeči v A-ÚTGM, fond TGM-R, kart. 427, zpráva byla publikována v upravené podobě roku 1933; 2) Publikovaná verze zprávy, kterou Masaryk upravil roku 1928 a byla otištěna roku 1933 v prvním vydání Cesty demokracie, přetisk srov. Zpráva ministerské radě, upravená prezidentem v roce 1928. In: Masaryk, Tomáš G.: Cesta demokracie I. Praha 2003, s. 403. 


\section{Rozdílné cesty: Masaryk a Dmowski v poválečném období}

Po první světové válce se životní dráhy Masaryka a Dmowského začaly výrazně rozcházet. Masaryk se stal prezidentem nové Československé republiky. Osobnost, která v předválečném období působila v českém veřejném prostoru dojmem kontroverzního a rozhodně nikoliv mainstreamového učence a jejíž politický proud představoval spíše menšinovou a marginální veličinu, získala v očích veřejnosti náhle potenciál společnost spojovat. Veřejnost sama chtěla v Masarykovi spatřovat ikonu a vůdce a dělo se tak $\mathrm{k}$ velkému počátečnímu překvapení Masaryka samého. ${ }^{12}$ Dmowski byl po skončení první světové války a následných mírových vyjednávání na polské politické i veřejné scéně do značné míry upozaděn. Významnou roli přitom sehrál i faktor, který v dějinách zaujímá zásadní roli, totiž náhoda a nepředvídatelná událost. Po skončení saint-germainských mírových vyjednávání s Rakouskem Dmowski na podzim 1919 vážně onemocněl zápalem plic, který jej ohrožoval i na životě. Choroba měla vleklý průběh a rekonvalescence trvala až do jara 1920. Dmowski, který v době onemocnění stále ještě byl ve Francii, absolvoval následně ozdravný pobyt v Alžírsku. V rozhodujících chvílích, kdy se formovala podoba poválečné polské veřejné a politické scény, nebyl Dmowski v zemi přítomen. Když Dmowski v květnu 1920 přijel do Varšavy, země již žila novými aktuálními událostmi - právě probíhající válka se sovětským Ruskem, v níž na polské straně zaujímal velitelskou roli Józef Piłsudski, v očích veřejnosti zastiňovala poněkud subtilní svět diplomatických vyjednávání, jež Dmowski v předchozím roce ve Francii vedl. Podle předního Dmowského životopisce Romana Wapińského, který se pokoušel srovnat Dmowského politickou koncepci s koncepcí Józefa Piłsudského, kladl Dmowski v duchu svého akcentování dlouhodobosti důraz na politické kroky, jejichž realizace měla trvat dlouhá léta, Piłsudski oproti tomu vynikal výzvami k činu a především činem samým. To se podle Wapińského projevilo i v rozdílném charakteru Dmowského a Piłsudského memoárových textů - zatímco Piłsudski činil ze svých vzpomínek předmět aktuální propagandy, Dmowski je zamýšlel přetvořit v základ politického myšlení. Piłsudski planul touhou po aktivitě a činu, byl dědicem polského povstaleckého romantismu, kdežto Dmowski představoval konstrukci, plán a rovnováhu, realismus s důrazem na vzdělání. ${ }^{13}$

V souvislosti s politickým a veřejným upozaděním rostla Dmowského nechut̉ vưči poválečnému politickému systému, kritika liberalismu a demokracie. Důrazem na pojem „krize“ se Dmowski blížil spenglerovsky laděným úvahám. Dmowského poválečné myšlení se oproti předválečným postojům podstatně transformovalo. Dmowski bezesporu vždy náležel $\mathrm{k}$ výrazně národně orientovaným politikům a myslitelům, v poválečném období však začal tíhnout ke krajně pravicovým tendencím. Prohluboval se i Dmowského antisemitismus, který byl v Dmowského uvažování vždy latentně přítomen. Ve druhé

12 K Masarykovu údivu nad vznikajícím kultem jeho vlastní osobnosti srov. Maxa, Prokop: T. G. Masaryk a stockholmská konference. In: Sborník vzpomínek na T. G. Masaryka. Praha 1930, s. 228-229.

13 Wapiński, R.: Roman Dmowski, s. 289, 317, 330, 383, 384; Wapiński, Roman: Wstęp. In: R. Dmowski. Wybór pism. Warszawa 1990, s. 35. 
polovině 20. let se Dmowski postavil do čela nacionalistické opozice vůči autoritativnímu Piłsudského tzv. sanačnímu režimu vzniklému roku 1926. Přestože část polských národovců spatřovala vzor ve fašismu, zůstává míra ovlivnění samotného Dmowského ze strany fašismu značně spornou. Dmowského výroky o fašismu byly značně rozporné a ačkoliv polští národovci chtěli v Dmowském spatřovat svého vůdce, Dmowski sám tuto roli odmítal. Způsobem svého jednání s lidmi ve svém okolí byl Dmowski vždy spíše demokratem. ${ }^{14} \mathrm{~V}$ duchu svých předválečných postojů $\mathrm{k}$ politice dával Dmowski přednost dlouhodobosti a dlouhodobému programu před politikou dne, což bylo směřování, kterému zvláště nacionalistická mládež nebyla ochotna naslouchat. Politiku Dmowski nadále vnímal jako v první řadě národově-osvětovou činnost. V momentě, kdy mládež očekávala od Dmowského silná hesla a výzvy k boji, tyto výzvy od Dmowského nepřicházely. Dmowski namísto toho pronášel rozsáhlé přednášky o dějinách civilizace, psal o rozdílu mezi taktikou boje a taktikou politickou a nepřestal zdůrazňovat dlouhodobou dimenzi vyhlídek jakéhokoliv programu a činu. ${ }^{15} \mathrm{~V}$ souvislosti s tím začal od počátku 30 . let Dmowského vliv na polské nacionalisty klesat a stárnoucí Roman Dmowski nalézal čím dál hůře posluchače.

Světonázorová východiska Masaryka a Dmowského byla vždy rozdílná, v poválečném období se však myšlenkový svět výrazně demokraticky orientovaného Masaryka od Dmowského postojů vzdálil více než kdykoliv předtím. Přesto lze v poválečných textech Masaryka a Dmowského nalézt četné paralelní a pro komparativní výzkum zajímavé linie. Masarykova kniha Světová revoluce a Dmowského dvoudílná kniha Polityka polska i odbudowanie państwa (obě vydány roku 1925) zachycují reflektivně pojaté vzpomínky $\mathrm{s}$ důrazem na válečné období, a to s hojnými přesahy do oblasti filosofie národních dějin, historické argumentace a hledání nové podoby Evropy. ${ }^{16}$ Dmowským silně ventilovaná nechut vůči podobě demokracie, jež se po první světové válce prosadila, nenacházela

14 Např. podle hodnocení historika Zygmunta Wojciechowského (1900-1955, zakladatele poznaňského badatelského ústavu Instytut Zachodni) vysloveného u přiležitosti Dmowského úmrtí roku 1939 byly snahy o hledání fašistických a nacistických vzorů v myšlení Romana Dmowského z podstaty věci ahistorické, nebot Dmowski byl podstatně starší než ideoví vůdci fašismu a nacismu a vypracoval své koncepce, které dále rozvijel, daleko dříve než samotný termín fašismus spatřil světlo světa. Wojciechowski, Zygmunt: Roman Dmowski - istota nieznana. Kronika Polski i świata, č. 31, 1939, přetisk in Wolikowska, I.: Roman Dmowski. Człowiek, Polak, przyjaciel, s. 266. Ke vztahu Dmowského k fašismu srov. zvl. Polonski, Antony: Roman Dmowski and Italian Fascism. Ideas into Politics. Aspects of European History 1880-1950. Sydney 1984.

15 Wasiutyński, Wojciech: Roman Dmowski a pokolenie Polski niepodlegtej. Myśl Polska, č. 15, 1. 8. 1964.

16 Zajímavou skutečností je, že kontrast mezi Masarykovým a Dmowského světonázorem byl mnohem patrnější pro badatele přistupující k problematice se znalostí historické zkušenosti druhé světové války a bezprecedentního nacistického totalitarismu než pro předválečné autory. Janoušek, E.: Masarykova Nová Europa a Dmowského Problems, s. 90, 94, 95, 98 světonázorový rozdíl mezi Masarykem a Dmowským vůbec nezmiňuje a při srovnání Masarykova a Dmowského př́stupu konstatuje „rozdíl v taktice, ale shodu v obecných cílech“, kdy Dmowski byl více politik, zatímco Masaryk pracoval výrazněji s vědeckou metodou, sociologickými a filosofickými prvky. V praktických důsledcích se podle Janouška Masaryk a Dmowski sobě velmi přiblí̌ili. Latawski, P.: The Discrepancy between State and Ethnographic Frontiers, s. 86 naopak zahajuje svůj výklad poukazem na kontrast mezi Masarykovými a Dmowského světonázorovými východisky (Dmowského sociální darwinismus oproti Masarykovu nábožensky založenému étosu, Masarykův demokratismus v kontrastu k Dmowského sklonu k obhajobě autoritářských režimů a pozdějšímu flirtování s italským fašismem, Masarykův odpor vưči antisemitismu jako protiklad Dmowského antisemitismu). 
u Masaryka obdobu. Přesto se však podobně jako v předválečném období u Masaryka i u Dmowského znovu projevil důraz na historicky podložený, na vzdělání a osvětě založený dlouhodobý národní program, kterému ne vždy konvenovaly momentální nálady obyvatelstva, rozhodující v demokratickém procesu o výběru toho kterého programu a o volbě zástupců lidu. $\mathrm{V}$ tomto směru vyjadřoval jistou skepsi vůči dobové politické praxi demokratického zřízení i Masaryk, když volal po hlubším politickém vzdělání voličstva, jež by občany přivádělo ke schopnosti lépe vyhodnocovat a tím i vybírat. ${ }^{17}$ S odkazem na názory Karla Havlička Borovského Masaryk zdůrazňoval, že politická negramotnost vede $\mathrm{k}$ neschopnosti chápat př́tomnost jako následek minulosti a mírí tak $\mathrm{k}$,diletantismu praxe“, jehož podstatou je „politika ode dne ke dni, snad od minuty k minutě, strašná politika konjekturální, která prýští z nevzdělanosti a strachu... metla vší politiky, také demokracie“. ${ }^{18}$ Jestliže však Masaryk uvedl, že „masa nemůže nikde řešit velké světové problémy“, nebot „nedostatečná kulturní příprava voličských mas... na to nestačí“, potom zároveň důrazně podtrhl, že vláda silných mužů jako náhrada demokracie „nemocné Evropě“ uzdravení nepřinese.${ }^{19}$ Navazoval tak na svůj předválečný postoj, kdy naznačil, že parlament je sice „rejdištěm demagogů a politických herců“, zároveň ale odmítal hojné protiparlamentní snahy konstatováním, že v demokratických systémech sice nutně vzniká oligarchie (potud Masaryk souhlasil s Michelsem), ale demokracie vždy produkuje jistý počet svobodných lidí, kteří autoritu kritizují. Ideálem podle Masaryka byla „aristokracie mravně dobrých a technicky použitelných lidi““ $s$ tím, že „ta někdy zřídka vznikne v demokracii, ale nikdy ne, kde vládne princip dědičnosti““. ${ }^{20}$ Masarykův teoreticky podkládaný odpor k vůdcovství představoval významný rozdíl oproti Dmowského postoji, nebot' Dmowski s představou vưdcovství ve svých textech a výrocích přinejmenším koketoval, ačkoliv sám vůdcovskou úlohu zjevně převzít nechtěl.

\section{České země a Československo na Masarykově mapě Nové Evropy}

Podle Masarykova pohledu z počátku 20. století byla historie české otázky geograficky vícevrstevná, znamenala rakouskou otázku, avšak i východní otázku a v některém ohledu i evropskou otázku. ${ }^{21} \mathrm{~V}$ předválečném období pokládal Masaryk Rakousko-Uhersko

17 Nový rok na Hradě - poselstvi prezidenta republiky. In: Masaryk, Tomáš G.: Cesta demokracie II. Praha 2007 [Čas, 2. 1. 1922; Národní listy, 2. 1.1922 a další čs. listy], s. 208; Masaryk studentstvu. In: Masaryk, Tomáš G.: Cesta demokracie III. Praha 1994 [Lidové noviny, 31. 3. 1924], s. 28.

18 Prezident Masaryk k 70. výroči smrti Havlícka. In: Masaryk, Tomáš G.: Cesta demokracie III. Praha 1994 [Národní osvobození, 29. 7. 1926 a v dalších čs. listech], s. 151.

19 Prezident Masaryk o Německu. In: Masaryk, T. G.: Cesta demokracie IV. Praha 1997 [Vossische Zeitung, 22. 1. 1933, 29. 1. 1933; Lidové noviny, 23. 1., 1933, 1. 2. 1933 a v dalších čs. listech], s. 330. V rozhovoru srov. též Masaryk o dnešni Evropě. In: Masaryk, Tomáš G.: Cesta demokracie IV. Praha 1997 [Berliner Tagblatt, 5. 10. 1932; České slovo, 5. 10. 1932 a v dalších čs. listech], s. 311.

20 Masaryk, Tomáš G.: Nesnáze demokracie. In: týž: Politika vědou a uměním. Praha 2011 [1913], s. 318.

21 Masaryk, Tomáš G.: Přednášky profesora T. G. Masaryka. In: týž: Ideály humanitní a texty z let 1901-1903. Praha 2011 [1901], s. 241-242. 
za jistou miniaturu Evropy a jejích problémů: „Rakousko se svými četnými národy je Evropa, svět v malém. “22

Masaryk napříč svým životem zdůrazňoval výjimečné postavení českých zemí v rámci slovanských národů - v předválečném období se této problematice explicitně věnoval v práci o Rusku a Evropě. Za války poté přirozeně daleko více než dříve akcentoval protiněmecký aspekt české polohy na mapě Evropy. Zdůraznil, že Čechy leží dále na západě než jiné slovanské země a tvořily v celých svých dějinách hráz proti Německu a klín mezi německými zeměmi na severu a na jihu. Masaryk v historickém ohledu navíc podtrhl, že přes komplikovanou geografickou polohu byl český národ od 7. století schopen díky síle své kultury odolávat německému tlaku a je tudíž i do budoucnosti životaschopný. Vedle německého tlaku Masaryk za války nově tematizoval i problém Mad’arů - invaze Mad’arů znesnadnila komunikaci mezi slovanskými národy a do jisté míry tím umožnila německý tlak. Mad’aři se podle Masarykovy interpretace stali přirozenými spojenci Němců. ${ }^{23}$

$\mathrm{V}$ předválečném období Masaryk poměrně důrazně odmítal historicko-geografickou interpretaci teritoria české otázky jako historického civilizačního mostu. ${ }^{24} \mathrm{~V}$ roli Československa jako historicko-kulturního mostu patrně Masaryk nevěřil ani po první světové válce, ačkoliv rostla společenská poptávka po tom, aby byla interpretace Československa jako mostu z prezidentových úst slyšena. Pouze na sklonku života Masaryk prohlásil, že se Československo nachází geopoliticky „na předělu mezi severem a jihem, východem a západem, mezi kulturami a národními rasami“, a letmo zmínil, že „jsme závora i pojítko, můžeme být překážkou nebo mostem““. ${ }^{25} \mathrm{~V}$ Masarykových předválečných textech se nevyskytovala ani idea českého teritoria jako hradby, at již proti Západu či Východu. Pojetí hradby začalo v Masarykově myšlení krystalizovat během první světové války, kdy chtěl Masaryk odůvodnit reálně politický zájem západních spojenců o českou problematiku vizí, podle které malé národy střední Evropy tvoří hradbu proti německému nebezpečí, což byl aspekt, který se měl stát základním geopolitickým argumentem pro poválečnou nezávislost malých středoevropských národů. Ve vztahu k Rakousku se Masaryk za války vrátil ke starší Palackého tezi o zrodu Rakouska v 16. století, podle níž Rakousko vzniklo jako hradba proti osmanskému nebezpečí. Protože však bylo osmanské nebezpečí pro Evropu již minulostí, Rakousko svou ideovou podstatu podle Masaryka ztratilo. Nedokázalo přitom nalézt novou identitu aktuální v kontextu moderního světa, ačkoliv ta se nabízela. Byla by jí obrana malých národů střední Evropy proti sílícímu Německu, která se též vyskytla již v Palackého myšlení, nenalezla ale v oficiálním Rakousku odezvu - naopak, Rakousko se stávalo čím dál závislejším na Německu. ${ }^{26}$

22 Masaryk, Tomáš G.: Rusko a Balkán. In: týž: Politika vědou a uměním. Praha 2011 [1913], s. 457.

23 Masaryk, Tomáš G.: Čechy a evropská krize. In: týž: Válka a revoluce II. Praha 2008 [The New Europe, 1917], s. 28-30.

24 Představy o Čechách jako mostu Masaryk důrazně odmítl v České otázce. Srov. Masaryk, Tomáš G.: Česká otázka - Naše nynějši krize. Praha 1947 [1895], s. 132-133.

25 O jiných věcech našich. In: Masaryk, Tomáš G.: Cesta demokracie IV. Praha 1997 [Lidové noviny, 25.12. 1934], s. 438.

26 Masaryk, Tomáš G.: Nová Evropa. Stanovisko slovanské. Brno 1994 [1920], s. 124-125. 
Masarykovo užívání termínů Evropa, západ, střed a východ nebylo ucelené. Výraz Evropa neměl v Masarykově pojetí hodnotovou povahu a byl užíván dle kontextu. Evropa byla pro Masaryka někdy prostě tím, co se nacházelo geograficky na západ od Ruska, v jiných kontextech Masaryk do Evropy zahrnoval i Rusko samotné. ${ }^{27}$ Zdá se, že o něco více hodnotově založeným způsobem přistupoval Masaryk k termínu Západ (ani tento pojem se však zdaleka nepřibližoval svou hodnotovou náplní například Masarykovu vnímání termínu křestanství).

Pozici české otázky v rámci Masarykova kulturně geografického členění Evropy lze v komplexnější podobě vysledovat ve válečných textech a zvláště v programovém spisu Nová Evropa z konce první světové války, kde toto členění dostalo politicky angažovanou podobu. S pojetím formulovaným v období první světové války Masaryk pracoval i v poválečném období. Masarykovu mapu Evropy je v této souvislosti s jistou nutnou mírou abstrakce možno rozdělit na čtyři části. ${ }^{28}$ První kategorii zemí představovaly západní demokracie ztotožněné s Británií a Francií a s o poznání méně tematizovanou Itálií. Ztělesňovaly pro Masaryka pozitivně hodnocený válečný tábor, státy usilující o „demokratickou organizaci lidstva“, státy „demokratické a republikánské, odvozující právo vlády z vůle lidu“. Jejich cíle byly „obranné a pacifistické“, a měly tudíž potenciál vést ke spravedlivějšímu poválečnému uspořádání nové Evropy. ${ }^{29}$

Druhou kategorii, blízkou první, představovalo Rusko. Masaryk se o Rusku vyjadřoval opatrně, snažil se zdůraznit podobnost jeho vývoje se západními mocnostmi, byl si ale vědom, že se mnohé charakteristiky západoevropských zemí k hodnocení ruské situace nehodily. ${ }^{30} \mathrm{~K}$ obezřetnosti v Masarykově postoji přispívala i akutní revoluční situace v Rusku na konci války, která neumožňovala bezpečně prognózovat další vývoj. V teritoriálním ohledu však Masaryk naznačil optimální vymezení poválečného ruského území, byt bez přesných kontur. Počítal jednoznačně s existencí nezávislého Polska (i když se nedotýkal otázky jeho východní hranice), vyjádřil však svou skepsi vůči emancipaci Ukrajinců, Bělorusů a dalších národností impéria, které nenavazovaly na historickou tradici nezávislé státnosti. $^{31}$

Třetí kategorií zemí byly negativně hodnocené „teokratické“ režimy, přičemž teokracií Masaryk rozuměl nadvládu jakéhokoliv dogmatu (at’ již náboženského či protináboženského/nenáboženského) a aristokratičnost společnosti. ${ }^{32}$ Do této skupiny zemí Masaryk řadil vedle středoevropských států (Německa a Rakouska-Uherska) rovněž geograficky

27 Srov. např. Masaryk, Tomáš G.: Rusko a Evropa I. Praha 1931, s. 10. V historickém ohledu Masaryk uvedl, že „Rusko je tím, čím Evropa byla“.

28 Ve výčtu není zařazena možná kategorie pátá - oblasti, o kterých se Masaryk v této souvislosti prakticky nezmiňoval. Jednalo se o státy Pyrenejského poloostrova, státy dnešního Beneluxu a Švýcarsko.

29 Masaryk, T. G.: Nová Evropa, s. 75-78.

30 Snaha ukázat na podobnost mezi Ruskem a západními mocnostmi evidentně vycházela z Masarykových válečných cílů a neodpovídala celé řadě Masarykových postojů formulovaných v období mimo probíhající válku. Když Masaryk pojednával o Rusku v souvislosti s ruskými zájmy, údajně totožnými se směřováním západních demokracií, připustil, že „[Rusko se] sice nehodilo do tohoto spolku [západních zemí], ale po svržení cara začalo usilovat o republiku“ (srov. Masaryk, T. G.: Nová Evropa, s. 77).

31 Tamtéž, s. 136-138.

32 Srov. Masaryk, Tomáš G.: Rusko a Europa II. Praha 1933, s. 638-640. 
odlišně situovanou Osmanskou říši. Ústřední mocnosti stavěly podle Masaryka na středověkém monarchismu a militarismu. Nemohly se vzhledem k povaze své politiky stát základem budoucí nové Evropy, protože jejich jednání a uvažování bylo „výbojné, militaristické..., protinárodní, aristokratické“. „Teokracie“ začala prohrávat, protože nadřadila anonymní stát národu, a tím i lidu. ${ }^{33}$

Čtvrtý region Evropy představovala oblast, kterou Masaryk nazýval jako „pásmo malých národů táhnoucí se od Laponska po Řecko“. Masaryk do něj zahrnoval všechna středoevropská, balkánská i severská etnika bez ohledu na skutečnost, zda dřive žila ve vlastním národním státě či nikoliv. Masaryk přirozeně tematizoval jednotlivé součásti pásma menších národů nestejnou měrou. V souvislosti s prioritou řešení české a slovenské otázky se vedle samotné československé problematiky nejintenzivněji zabýval polskými a jihoslovanskými teritorii. Skandinávské oblasti věnoval naproti tomu jen minimální pozornost. Př́klad severských národů sloužil Masarykovi v historicko-aktualizačním ohledu především jako argument pro skutečnost, že malý národ může být úspěšný. ${ }^{34}$ Intenzivněji tematizovanou část pásma menších národů lze s jistou mírou nepřesnosti označit dnes užívaným termínem středovýchodní Evropa (resp. východní střední Evropa). Tuto část kontinentu Masaryk vymezoval jako oblast obklopenou během historického vývoje Němci, Osmany a Rusy, jejichž snahy o expanzi situaci v regionu pravidelně destabilizovaly. V průběhu novověku se ukazovalo, že nejzřejmější bude expanze německá, které napomáhala jak existence německých kolonií „vražených jako tvrze do cizího území“, tak i konfuzní etnické hranice mezi Němci a neněmeckými národnostními skupinami. Němci se v regionu „začali chovat jako panský národ, nadřadili svou kulturu nad kultury domácí a zpo̊sobili úpadek dříve vzkvétajících zemí“. Kontrast husitských a pobělohorských Čech byl v tomto směru pro Masaryka nejvýraznějším příkladem. ${ }^{35}$

Ve vztahu k pásmu malých národi̊ Masaryk za první světové války často užíval termíny „Východ“ či „východní Evropa“, čímž především naznačoval rozdíl mezi Východem jako oblastí malých národů a Západem, kde převládaly národy velké. Do tohoto Východu tudíž nezařazoval Rusko (aniž by jej ale zároveň vylučoval z Evropy), i když v odlišných souvislostech Rusko s Východem asocioval. Jindy zase Masaryk hovořil o tomtéž teritoriu jako o střední Evropě. ${ }^{36} \mathrm{Na}$ druhé straně však Masaryk v poválečném období označoval české země za součást kulturního Západu, a to oproti jiným partiím pásma malých národů, Uhersku, Polsku a balkánským zemím, které spolu s Ruskem řadil spíše k Východu. ${ }^{37}$ Neustálenost Masarykova pojmového aparátu svědčí o skutečnosti, že zmíněná geografická označení byla pro Masaryka instrumentální a závisela plně na kontextu - termíny východ, střed či západ nebyly spojovány s žádnými inherentními hodnotami. Masarykův vztah ke geografickému vymezení Východu a Západu byl značně elastický a lze vyslovit tezi, že byl závislý na okolnostech, za nichž bylo dané geografické ohraničení vyjádřeno.

33 Masaryk, T. G.: Nová Evropa, s. 97, 181.

34 Srov. Tamtéž, s. 101: „Jako český národ, podobně i Dánové, Norové, Švédové, Finové jsou důkazem, že kulturní zdatnost nemůže se měřit pouze kilometry území ani číslicemi statistiky.“

35 Tamtéž, s. 82-83, 87-103.

36 K této terminologické neujasněnosti srov. např. Tamtéž, s. 118, 134.

37 Masaryk, T. G.: Světová revoluce, s. 502, 516. 
Např́klad v amerických přednáškách z roku 1902 např́klad Masarykovi nečinilo problém, aby uvedl, že „Karel IV. založil první universitu východní Evropy““. ${ }^{38}$ Vedle toho dle jiného Masarykova členění Německo, Rakousko a Rusko do jisté míry hodnotově náležely k téže části Evropy. ${ }^{39}$ České země v Masarykově výkladu náležely podle kontextu výkladu někdy k západu, jindy ke středu Evropy a jindy opět $\mathrm{k}$ východu.

Představa evropského Západu jako oblasti velkých národů a Východu jako pásma malých národů se vyskytla již v Masarykově memorandu Independent Bohemia z roku 1915. Masaryk zde jako Východ označoval bez jakýchkoliv hodnotových konotací oblasti, které se nacházely geograficky na východ od Německa. ${ }^{40}$ Teoretické a kulturně historické problematice malých národů se Masaryk za války věnoval rovněž ve statích vzniklých na základě přednášek na univerzitní půdě. Západ a Východ Evropy podle jeho názoru nebylo možné ostře rozdělit, Německo a Rakousko-Uhersko patřily na Západ i na Východ. Zároveň Masaryk zdůraznil, že pokud Západ a Východ nejsou ostře odděleny, objeví se na mapě též zvláštní etnologické pásmo (pásmo malých národů), to, čemu se říká střední Evropa. ${ }^{41}$

Západ pokládal Masaryk v poválečném období za jeden kulturní celek zahrnující Francii, Anglii, Itálii a další románské státy, a rovněž USA. ${ }^{42} \mathrm{~K}$ Západu ve středověku podle Masaryka náleželo i Německo, v průběhu novověku se ale čím dál více izolovalo a tato separace se prohlubovala se vzrůstající mocí Pruska. ${ }^{43}$ Pro Masarykovy texty byla rovněž př́značná určitá tendence uvést do spojitosti stř̌edovýchodní Evropu a západní Evropu na jedné straně a Německo a Rusko na straně druhé. Důležitá je v této souvislosti teze, podle které byly země středovýchodní Evropy v Masarykově hodnocení společensko-politickou strukturou západním demokraciím bližší než Ústřední mocnosti. Masaryk postuloval jistou formu př́ibuznosti mezi západoevropským (britským, francouzským) myšlením a myšlením menších slovanských národů a tuto spřízněnost stavěl do kontrastu vůči německé duchovní kultuře. Zatímco západoevropské myšlení a myšlení národů na východ od Německa reprezentovalo humanitní a demokratický ideál, značná část německých vzdělanců podle Masaryka ve svém intelektuálním aristokratismu zastávala neudržitelnou anachronickou tezi o nadčlověku. ${ }^{44}$ Německé, rakouské a ruské myšlení představovaly v Masarykově vnímání společně zástupce „zapadajícího rusko-prusko-ra-

38 Husũv odkaz. In: Masaryk, Tomáš G.: Politika vědou a uměním. Praha 2011 [1912], s. 234; Masaryk, T. G.: Přednášky profesora T. G. Masaryka, s. 241-242.

39 Srov. zmínku o „zapadajícím rusko-prusko-rakouském carismu“. Masaryk, T. G.: Světová revoluce, s. 438.

40 Memorandum bylo uveřejněno až po skončení války, srov. přetisk Masaryk, Tomáš G.: Nezávislé Čechy. In: týž: Válka a revoluce I. Praha 2005 [1915], s. 60-72.

41 Masaryk, Tomáš G.: Problém malých národů v europské krizi. In: týž: Válka a revoluce I. Praha 2005 [1915], s. 119.

42 Srov. též z poválečné doby jeden z Masarykových četných rozhovorů s novináŕi, Interview pro Cosmopolitan Magazine. In: Masaryk, Tomáš G.: Cesta demokracie IV. Praha 1997 [A ÚTGM-CD 29, 14. 5. 1929], s. 36, kde Masaryk uvádí: „Američané jsou ve skutečnosti Evropany, postavenými do jiných přírodních podmínek."

43 Masaryk, T. G.: Svètová revoluce, s. 409.

44 Masaryk, Tomáš G.: Slované ve světě. In: týž.: Válka a revoluce I. Praha 2005 [La nation tchèque, 15. 3. 1916], s. 202. 
kouského carismu“.45 České země podle Masarykova hodnocení ve svých dějinách kulturně a historicky náležely $\mathrm{k}$ Západu, přičemž vedle přirozeně nejsilnějších německých vlivů se již ve středověku projevovaly též vlivy francouzské a italské. Husitství bylo jasným příkladem spjatosti se Západem, s viclefovským učením v Anglii. Česká reformace vytyčila ideály, které západní reformace a revoluce později uskutečňovaly. Západním myslitelem byl Komenský, který byl ovlivněn anglickými teoriemi. Za habsburské nadvlády se prosadil ,jednostranný vliv německý“, ale české obrození cíleně hledalo jiné směry. S Východem byly podle Masaryka historické a kulturní styky mnohem skrovnější než se Západem. Přirozeně existovaly intenzivní styky s Polskem a Uherskem, avšak Rusko a jihoslovanské země představovaly až do konce 18 . století neznámý prostor. ${ }^{46}$

V Masarykově projektu nové poválečné Evropy figurovaly v zásadě dvě střední Evropy - západní německá a východní, reprezentovaná menšími národy. Masaryk se ve své koncepci programově snažil oddělit českou otázku od otázky německé a postavit českou otázku do souvislosti s národy prožívajícími analogický historický osud. Programové rozdělení střední Evropy na západní a východní část mělo potom především ukázat na společný zájem menších národů středovýchodní Evropy. Nejasný zůstal v projektu Nové Evropy Masarykův postoj ke zbytkovému (německému) Rakousku a k poměru Rakouska vůči poválečnému německému státu. Avšak vzhledem ke skutečnosti, že Masaryk německé Rakušany pokládal v národnostním ohledu de facto za Němce, neřadil evidentně území německého Rakouska do východní střední Evropy, jejímž základním definičním prvkem byla vize teritoria menších národů. ${ }^{47}$ Svébytnost Rakouska zdůraznil Masaryk teprve po první světové válce ve Světové revoluci roku $1925 .{ }^{48}$

Pro východní část střední Evropy byl Masaryk nucen nalézt společnou identitu, která by tento prostor stmelovala a činila z něj smysluplný celek. Již samotná Masarykova formulace této identity však ukazovala, že se v mnoha směrech jednalo spíše o veličinu vynalézanou než nalézanou. Výsledky Masarykova hledání společných identitotvorných činitelů národů středovýchodní Evropy nebyly nejlepší a zůstaly v příliš abstraktní rovině. Hlavní uvažované spojence, Československo, Polsko a Království Srbů, Chorvatů a Slovinců, tak měl vzájemně poutat „slovanský cit a jednotné dějinné vědomi“. Masaryk si uvědomoval deficit hmatatelného pozitivního základu společné identity a v podstatě sám přiznal, že vymezení společného zájmu tohoto evropského makroregionu bylo především negativní, obranné - nutným sjednocujícím heslem se stávala aliance proti pangermanismu. Avšak ani existence německého nebezpečí nemohla hrát v jihoslovanském prostředí tak silnou úlohu jako v československém a polském př́ípadě.

Nalezení jiného konkrétního tmelu než protiněmecké karty bylo nicméně velmi těžké. Svědčí o tom Masarykem uváděné historické příklady, jež se s ohledem na vztahy mezi

45 Masaryk, T. G.: Světová revoluce, s. 409, 438.

46 Masaryk, T. G.: Světová revoluce, s. 516.

47 Takové interpretaci nasvědčuje i Národopisná mapa Evropy, která je př́ilohou Masarykovy publikace Nová Evropa.

48 „Redukované Rakousko nabývá svého původního významu, jako ,říše východní‘. Předpokládám, že se udrží vedle Německa samostatným. To je si přát nejen politicky, nýbrž i kulturně“ Masaryk, T. G.: Světová revoluce, s. 508-509. 
Československem a Polskem ve všech případech přímo či nepřímo dotýkaly německé otázky. Masaryk vycházel v té souvislosti z předpokladu chronologicky korespondujících českých a polských historických úspěchů a rovněž neúspěchů, hledal paralely mezi polským vítězstvím nad Řádem německých rytî́r̊ u Grunwaldu (1410) a zdarem husitského hnutí, jež společně zastavily německý pochod na východ, či mezi českou porážkou na Bílé hoře (1620) a úpadkem polského stavovského státu (Rzeczpospolita). V aktuálním kontextu potom zdůrazňoval, že „bez svobodné Polsky nebude svobodných Čech a Slovenska, bez svobodných Čech a Slovenska nebude svobodné Polsky“. Poláci v Masarykově hodnocení zaujímali vǔči Prusku totéž postavení, co Češi vǔči Rakousku. Obnovení Polska proto podle Masaryka mělo být porážkou pruského militarismu stejně tak, jako by byl vznik Československa a Jugoslávie záhubou pro Rakousko-Uhersko. Ve vztahu k Jugoslávii však Masaryk další historické př́klady společného geopolitického zájmu jen těžko nalézal (k mad’arské otázce Masaryk patrně z taktických důvodů přistupoval velmi opatrně) a jeho argumentace se proto omezila na př́liš obecné konstatování identifikující Jihoslovany s protiněmeckou hrází na jihu. ${ }^{49}$

\section{Polsko na Dmowského mapě nové Evropy}

Dmowski situoval podle své poválečné koncepce Polsko do „míst, kde končí západní Evropa a která představují východiště do rozlehlých rovin Východu“, oblast "položenou mezi dvěma velkými zeměmi, Německem a Ruskem, kde není místo pro malý, slabý stát“" ${ }^{50}$ Polsko sice historicky sahalo daleko na východ, avšak vliv polské civilizace byl nesmírně nerovnoměrný, neklesal přitom lineárně od západu $\mathrm{k}$ východu, nýbrž v etnicky a civilizačně cizím území se nacházely četné polské ostrovy a na druhé straně poměrně daleko na západě byla území takřka úplně nepolská. ${ }^{51}$

Dmowski zdůrazňoval, že geografickým těžištěm polského národa je Visla. ${ }^{52} \mathrm{~S}$ tímto postojem konvenoval i Dmowského poválečný názor zdůrazňující vedle páteřní úlohy Visly v aktuálním kontextu i význam jejího ústí do Baltského moře. Geografické Polsko podle Dmowského poválečného pohledu ve svých dějinách zaujímalo především celé povodí Visly, velkou část povodí Odry a část povodí Němenu. Výbojná politika Římskoněmecké ŕišse, Řádu německých rytířu a Hanzy v minulosti způsobila, že ústí Odry a Němenu se dostaly do německých rukou, což přispělo k citelnému oslabení Polska. Bez kontroly nad ústím Visly by podle Dmowského Polsko bylo zemí odsouzenou k cizí nadvládě. ${ }^{53}$

Vývojem Dmowského myšlení se prolínala myšlenka, že Poláci musí aspirovat na pozici velkého národa, jinak jsou v geografické pozici, v níž se polské země nacházejí, odsou-

49 Masaryk, T. G.: Nová Europa, s. 161-164.

50 Dmowski, Roman: Polityka polska i odbudowanie państwa I. Częstochowa 1937 [1925], s. 23-26, 33.

51 Tamtéž, s. 23-26, 33.

52 Dmowski, Roman: Niemcy, Rosja i kwestja polska. Częstochowa 1938 [1908], s. 244.

53 Dmowski, Roman: Niemcy a Polska. In: týž: Świat powojenny i Polska. Częstochowa 1937 [1931], s. 250. 
zeni k záhubě. ${ }^{54}$ Dmowski před válkou srovnával vzhledem k pozici polské otázky Poláky spíše s malými nevládnoucími národy než s národy velkými, domníval se ale, že v rámci kategorie nevládnoucích národů zaujímali Poláci specifické postavení, nebot oproti většině z nich měli velkou výhodu v tom, že byli historickým národem, měli tradici státu a historické sociální vrstvy, jež zajištovaly kontinuitu národa. ${ }^{55} \mathrm{Na}$ druhé straně však polská historická tradice představující kontinuitu nebyla podle Dmowského tak silná a nikdy nedosáhla té úrovně, jež byla známa z velkých západoevropských zemí. Dmowski v tomto ohledu poukázal na rozdíl mezi Polskem a Západem, k němuž Polsko přímo nenáleželo.

S ohledem na mentální geografii v Dmowského myšlení je třeba zdůraznit, že Dmowski příležitostně rozlišoval východní Evropu a Orient ( $\mathrm{k}$ němuž v jeho vnímání do značné míry náleželo Rusko). Rovněž termíny Západ a západní Evropa nebyly v Dmowského vnímání totožné. Kulturním, hodnotovým pojmem byl Západ, západní Evropa bylo spíše nehodnotové, geografické označení. Polsko v Dmowského pojetí náleželo k Západu, nikoliv však k západní Evropě. Východní Evropa představovala geografický podpojem Západu. Z Dmowského výkladu je zřejmé, že Západ byl do značné míry vymezen nábožensky - Byzanc, odkud přišlo křestanství do Ruska, označoval Dmowski jednoznačně jako orientální stát. Na druhé straně je z jiných míst Dmowského výkladu zřejmé, že Dmowského ztotožnění Západu se světem katolického a protestantského křestanství nebylo jednoznačné - Dmowski např́iklad uváděl, že Polsko je „západní svým náboženstvím a východní svou civilizací “. ${ }^{6}$

Dmowského postoj k pozici Polska na kulturní mapě Evropy byl závislý na kontextu a nelze jej považovat za jednoznačný. V kontrastu k pravoslavnému Východu řadil Dmowski polská území jednoznačně k západní civilizaci, na druhé straně však v případech, kdy Polsko srovnával s evropským Západem, zřetelně zdůrazňoval, že mezi Polskem a Západem existují zřejmé kulturní odlišnosti. ${ }^{57}$ Dmowského rozporuplný postoj k pozici Polska mezi Západem a Východem lze dokumentovat zvláště na základě stati Wschod $i$ Zachód w Polsce z roku 1926, která se problematice Západu a Východu podrobně věnovala a svými východisky navazovala na Dmowského předválečné úvahy o podstatě ruské mentality, odlišné od mentality západní. Podstatou Západu bylo podle Dmowského v historickém ohledu právo a právní vědomí, které představovalo hlavní dědictví Říma. Právě právní vědomí odlišovalo Západ od jiných civilizací. Směrem na východ se v Evropě smysl pro právo pozvolna vytrácel. Díky právnímu vědomí a silným institucím, které na něj navazovaly, byly západoevropské země schopny vybudovat silné státy postavené nikoliv na vojenské síle či moci panovníka, ale na dlouhodobosti, jež spočívala v kontinuitě institucí. Kontinuita působila, že se vedle státu vytvořila i společnost, která nezávisela na integrující síle vojenské moci či osoby toho kterého panovníka. Společnost založená na institucích byla schopna zachovat svou politickou organizaci i tehdy, kdy byla moc státu otřesena či dokonce stát načas zanikl. I v případech, kdy se země dostala pod

54 Týž.: Polityka polska i odbudowanie państwa I., s. 23-26, 33.

55 Týž: Upadek myśli konserwatywnej w Polsce. Częstochowa 1938 [1914], s. VIII.

56 Týž: Problems of Central and Eastern Europe. London 1917, s. 48.

57 Týž.: Upadek myśli konserwatywnej w Polsce, s. 59. 
vládu cizích nájezdníků, nebyli tito nájezdníci schopni společnost zničit či ji asimilovat, ba naopak, společnost v takových případech asimilovala je. Státy, které se na historické scéně objevily později, například státy střední a středovýchodní Evropy, se projevily jako daleko méně trvalé instituce. Hranice se zde neustále měnily a celé velké státy jako Polsko, české země a Uhersko mizely z mapy. ${ }^{58}$ Polsko, české země, Uhersko a Rusko zažily ve svých dějinách podle Dmowského hodnocení diskontinuitní historický vývoj, což je svým způsobem typologicky řadilo k vzájemně podobnému typu státu neopírajícímu se o dostatečně rozvinutou společnost. ${ }^{59}$

Indikátorem příslušnosti Polska k západní civilizaci byla v Dmowského vnímání míra, do jaké bylo v Polsku respektováno právo a do jaké byl přítomen smysl pro právo, ztělesňující kvintesenci západního civilizačního okruhu. ${ }^{60}$ Dmowski zdůrazňoval, že vždy existovaly velmi velké kulturní rozdíly mezi západem a východem polského území, významná civilizační hranice mezi západním a východním civilizačním okruhem dokonce podle řady kritérií procházela právě napříč polským územím. ${ }^{61} \mathrm{~V}$ rámci Evropy bylo podle Dmowského Polsko zemí s největšími vnitřními rozdíly, které se projevovaly nejen ve stupni, ale i v charakteru civilizace. Dmowski uvedl, že „čím více se v Polsku posouváme od západu na východ, tím slabší je smysl pro právo“. Východní části Polska zaostávaly podle Dmowského za západními „přinejmenším o dvě století“. ${ }^{62}$

Polský raně středověký piastovský stát Měška I. (vl. cca 962-992) a Boleslava Chrabrého (vl. 992-1025) byl sice podle Dmowského silným státem, avšak nikoliv státem zbudovaným na evropských (římských) základech. Podle Dmowského hodnocení polský středověký stát nevytvořil kontinuitní instituce ani společnost a byl tudíž ř́̌š́, nikoliv státem. Moc Piastovců vyrostla na způsob rozmachu východních říší, díky výjimečnosti konkrétního panovníka. Polsko se však pozvolna měnilo na stát západního typu, a to i v době rozštěpení (12.-13. století). Hlavním činitelem působícím pozápadnění byla podle Dmowského církev. Její důraz na právo a instituce byl ve vztahu k budování státu největším historickým přínosem katolicismu. Vnitřní znovusjednocení Polska za vlády Vladislava I. Lokýtka (vl. 1320-1333) a Kazimíra Velikého (vl. 1333-1370) se již vyznačovalo západními rysy, nebot kodifikované právo převládlo nad zvykovým. Romanizace a europeizace dále postupovala za Jagellonců. Dmowski v této souvislosti zdůraznil úlohu měst („dílen civilizace“), která sice v této epoše začala již pozvolna hospodářsky slábnout, žila však „plným evropským životem“. ${ }^{6}$

Za vlády posledního Jagellonce (Zikmund II. August, vl. 1548-1572) se rozlehlá východní teritoria spojila s Polskem v jeden celek: „Moc Polska se sice zdvojnásobila, avšak jeho západní charakter se náhle stal o polovinu slabším“. Polsko sice podle Dmowského

58 Týž: Wschod i Zachód w Polsce. In: Týž: Pisma X. Częstochowa 1939 [1926], s. 75-76.

59 Týž: Problems of Central and Eastern Europe, s. 59.

60 Týž: O praworzadności v Polsce. (Przemówienie, wygłoszone w Bydgości dnia 3 kwitnia 1927 r.). In: týž: Pisma X. Częstochowa 1939, s. 147.

61 Týž: Polska jako wielkie państwo. (Mowa, wygłoszona w Poznaniu dnia 28 czerwca 1929 roku podczas uroczystości obchodu dzisięciolecia traktatu wersalskiego). In: týž: Pisma IX. Częstochowa 1939, s. 9.

62 Týž: Nowy sejm i politika wewnętrzna. In: týž: Pisma X., s. 220.

63 Dmowski, R.: Wschod i Zachód w Polsce, s. 79-82. 
přinášelo do teritorií na východě západní civilizaci, ale i Východ působil zpětně na západnější části Polska. Východ ovlivnil zvláště životní styl a hodnoty vyšších vrstev společnosti, jež stát ovládaly, což mělo velký vliv na polské myšlení a politické instituce polského stavovského státu. Příznivě v Polsku podle Dmowského nadále působili jiní činitelé než samotný rozkládající se stát - právní instituce, církev a hospodářství nadále přibližovaly Polsko Západu, „společenské instinkty“ byly čím dál evropštější, nejsilněji v západních částech Polska, daleko méně v „divokém Polsku“. Těžkou ránu znamenaly pro Polsko polsko-švédské války o vliv v Pobaltí (17. století), které zemi posunuly v rozvoji „o dvě stě let zpět" - žádná jiná událost v polských dějinách neznamenala podle Dmowského hodnocení pro Polsko takovou porážku.

Výrazně „východním“ činitelem byli v Polsku podle Dmowského hodnocení Židé, kteří s největšími obtížemi přijímali římskou civilizaci a po švédských válkách výrazně vzrostla jejich pozice v rámci Polska. V postoji k východnímu charakteru židovského národa byl však Dmowski nekonsekventní, nebot Židy v jiných souvislostech označoval za nositele německých vlivů, přičemž na mnoha místech je z Dmowského textů patrné, že Dmowski Německo a Rakousko řadil ke kulturnímu Západu.

V záborovém období pokračoval podle Dmowského v pruském záboru „pohyb k západu“, rostl smysl pro právo a právní instituce. Podobný vývoj, i když ve více domácím, polském duchu (a rovněž v duchu více latinském), probíhal i v ruském záboru (Polském království), jehož politicko-právní základy byly podle Dmowského hodnocení položeny Napoleonem v rámci Knížectví Varšavského (1807-1813). Ruské vlivy byly v počátečním období jen slabé. Vývoj se obrátil až po roce 1831, kdy začal podle Dmowského interpretace útok proti všem prvkům západní civilizace. Řada polských institucí byla ale nadále zachována a země si udržela západní charakter. Teprve po roce 1863 začal Západ v Polském království zcela couvat před Východem - v posledních dvou desetiletích 19. století byl podle Dmowského vliv Východu čím dál více cítit, začal prosakovat skrze mládež, která studovala v Rusku a nechala se ovlivnit ruským způsobem revolučního myšlení. Východní části Polska vstoupily podle Dmowského do 20. století jako civilizačně mnohem méně západní teritorium než jakým byly o několik generací dříve. ${ }^{64}$

Rysem východní civilizace v Polsku bylo stavění násilí nad právo, radikalismus a časté oscilování mezi dvěma krajnostmi - společenským radikalismem (blízkým komunismu a anarchismu) na jedné straně a monarchismem na straně druhé. To byly podle Dmowského hodnocení charakteristické rysy Východu, Ruska řídícího se heslem „carismus, nebo bolševismus“. Jestliže na Západě po převratech docházelo k ustavení pevného právního pořádku, na Východě po zvratech a společenských transformacích rostla nejistota a anarchie, jež bránily rozvoji. ${ }^{65}$

Dmowski podtrhával polskou výjimečnost v evropském kontextu, která naznačovala roli mostu a zároveň hradby. Termín „střední Evropa“, který by tuto koncepci mohl vystihovat, se však v Dmowského textech vyskytoval relativně málo. S termínem „střední Evropa“ operoval Dmowski především v rámci válečného textu Problems of Central and

64 Tamtéż, s. 83-87.

65 Tamtéz, s. 73-91. 
Eastern Europe z roku 1917. V jiných Dmowského textech lze koncept střední Evropy spíše vytušit z kontextu, aniž by byl pojmově uchopen.

Na mapě Evropy rozlišoval Dmowski čtyři až pět typů národů a tím i stejný počet makroregionů. V západní Evropě se hranice států utvořily brzy, v průběhu středověku. Ve střední Evropě a na Balkáně byl vývoj diskontinuitní. Staré státy zmizely z mapy (Polsko, České království, Mad’arsko, Chorvatsko, Srbsko, Bulharsko, podunajská knížectví, Benátská republika). Morální vazby mezi státem a jeho obyvateli byly značně slabé, v polských teritoriích neexistovaly vůbec. Zatímco v západní Evropě se vyvinuly státní národy, ve střední Evropě se prosadila jazyková a etnografická definice národa. Německo a Itálie představovaly přechodnou kategorii mezi středoevropskou a západoevropskou situací. Dmowski v této souvislosti uvedl, že na západních hranicích Německa a Itálie se uplatňovalo spíše západoevropské, na východních poté středoevropské pojetí - Italové z jižního pobřeží Francie neměli problém identifikovat se s Francií, Italové z Rakouska-Uherska byli však ardentními italskými vlastenci. Obyvatelé severomořského pobřeží hovořící dolnoněmeckými dialekty se na jedné straně hranice hlásili bez problému k Holandsku a na druhé k Německu, na východním pomezí německého etnického prostoru byl však nepřítelem státu každý, kdo nenáležel k německému etniku ${ }^{66}$ Charakteristickým znakem východní Evropy jako další kategorie byla podle Dmowského dosud nepřekonaná národní indiference lidových mas, ačkoliv se zde postupně s rostoucí vzdělaností a vznikem střední třídy (inteligencia) rodila idea jazykově založeného vymezení národa. Polsko se podle Dmowského nacházelo na pomezí mezi střední a východní Evropou, tvořilo přechodnou kategorii mezi středem a východem podobně jako Německo a Itálie mezi západem a středem - na západě Polska převládalo středoevropské pojetí národa, na východě dosud vládla národnostní indiference (východem Polska rozuměl Dmowski především teritoria, která Rusko po dělení Polska oddělilo od Polského království a přičlenilo k samotnému Rusku).

Postoj k hodnocení Západu jako kulturního pojmu se v rámci vývoje Dmowského myšlení proměňoval. Z Dmowského textů je patrné, že Dmowski byl v poválečném období vůči západní civilizaci velmi kritický a tato kritika se prohloubila v době velké hospodářské krize na přelomu 20. a 30. let. Na druhé straně bylo však Dmowského kritické hodnocení Západu nanejvýš rozporuplné a rozhodně jej není možno označit za jednoznačné. Dmowski nezavrhoval hodnotové dědictví západní civilizace, spíše z konzervativních pozic odsuzoval její současný stav, který se od historických hodnot Západu odchýlil. Jak již bylo zmíněno, za nejzákladnější výdobytek západní civilizace pokládal Dmowski společnost založenou na právu. V tomto směru se podle Dmowského Polsko nadále mělo přibližovat západnímu modelu, nebot jen stát založený na právu mohl být podle Dmowského silným státem. ${ }^{67}$ Dmowského poválečný kritický postoj vůči západní civilizaci konvenoval spíše s tehdejším Dmowského kritickým pohledem na protestantský a zvláště anglosaský svět, který kontrastoval s Dmowského předválečným anglofilstvím a jistým dřivějším obdivem vůči civilizačním pokrokům protestantských zemí - Dmowski

66 Dmowski, R.: Problems of Central and Eastern Europe, s. 19.

67 Týž: O praworzadności v Polsce, s. 147. 
moderní západní civilizaci podobně jako Masaryk ztotožňoval především s protestantským germánským (a zvláště anglosaským světem), zatímco dědictví katolického světa či francouzské civilizace s termínem Západ asocioval daleko méně. Nová Dmowského poválečná kritika protestantského světa byla v protikladu k jistému zhodnocení úlohy evropského románského katolického jihu (Francie, Itálie) v Dmowského uvažování. Dmowski v poválečném období v kontextu silně tematizované krize Západu otevřel otázku nadcházejícího úpadku protestantských národů, nedomníval se však, že úpadek protestantských zemí bude rychlý. Jednalo se podle jeho názoru o země, které nahromadily v průběhu staletí velké množství lidského i finančního kapitálu, ze kterého mohou ještě dlouho žít a uplatňovat převahu nad ostatními. ${ }^{68}$

V novém historickém kontextu, kdy podle Dmowského začal úpadek Západu, Polsko nemělo jít cestou jeho slepého následování, které dosud převládalo. Polsko se podle Dmowského mělo rozhodnout, zda „se bude vléct na ocase upadající Evropy, ke které ho táhnou vnější vlivy a vlastní sklon k bezmyšlenkovitému napodobování“, nebo zda pochopí podstatu svého geografického postavení, duchovní uspořádání polského národa, které mu „vykazuje místo v druhé Evropě, dnes skromnější, ale mající před sebou lepší, jistější budoucnost“ ${ }^{69}$ Dmowski tedy otevřeně exaltoval „druhou Evropu“, kterou lze interpretovat nejen jako východní Evropu, ale též jako celé dosavadní evropské „nejádro“, evropskou periferii a semiperiferii. To se projevovalo např́íklad v novém Dmowského kladném hodnocení italské kultury, která měla podle Dmowského pohledu „silné nervy“. Dmowského „druhá Evropa“ byla konstruována vlastně na základě zvláštní syntézy „starých národů“, které kdysi byly centrem a posléze ustoupily z výsluní, a mladých národů (Poláci), jež dosud nedozrály a byly tudíž „čilejší“. Dmowski tak předpokládal svého druhu alianci minulosti a budoucnosti proti přítomnosti, proti částem světa, jež byly právě na výsluní a které se v probíhající historické epoše podle Dmowského dostávaly do krize.

Jestliže dříve Dmowski pokládal přibližování Polska západní civilizaci za pozitivní fenomén, poté po první světové válce spatřoval budoucí perspektivy Polska spíše v rysech, ve kterých se polská civilizace od západní odlišovala: „Stojíme daleko v týle za národy v popředí naší civilizace. Nemáme jejich moc... máme ale jisté hodnoty, které by se nyní oněm národům hodily a uchránily by je od mnoha nebezpečí.“ Těmito hodnotami byl podle Dmowského silný vztah k náboženství, národní cit, vazba na vlast. Ovlivněn ruskou emigrační geopolitikou prohlásil Dmowski Evropu za pouhý poloostrov Asie. V historickém ohledu Dmowski odmítl především přináležitost polské historie k té části dějin Západu, která byla spjata se zámořskou expanzí a která podle Dmowského v dlouhodobé perspektivě zpo̊sobila problémy západních zemí. Polsko se na těchto činech nijak nepodílelo ani z nich nemělo žádný prospěch, a nebyl proto podle Dmowského důvod, proč by se Polsko mělo jakkoliv hlásit $\mathrm{k}$ důsledkům těchto činů (ba na základě nich i trpět) v době, kdy se mimoevropský svět emancipoval a původní komparativní výhoda Západu se stávala jeho nevýhodou. ${ }^{70}$

68 Týž: Świat powojenny i Polska, s. 273.

69 Týž: Po przewrocie. (Artikuły drukowane w Gazecie Warszawskiej od czerwca do grudnia 1926 r.). In: týž: Pisma X., s. 54. 


\section{Závěr}

Masarykův a Dmowského pohled na pozici české (československé) a polské otázky v rámci kulturní mapy Evropy se lišil tím, že Dmowski Polsko pokládal za okraj Západu a západní civilizace, zemi nacházející se vždy ve svých dějinách na civilizačním pomezí. Masaryk interpretoval českou otázku jako geograficky mnohovrstevný problém zahrnující v sobě otázku Rakouska, slovanství i Evropy jako celku, vnímal ji však v rámci těchto kontextů jako otázku do značné míry centrální a neasocioval ji s geografickými „okraji“. České země v historické perspektivě pojmenovával jako odvěké hospodářské jádro Rakouska, předvoj slovanského světa a teritorium, kde byla husitstvím nastartována cesta Evropy k reformaci a tím i k modernitě.

Masarykův a Dmowského pohled na pozici české a polské otázky na mapě Evropy se výrazně přiblížil v době první světové války, kdy Masaryk a Dmowski prakticky shodně tematizovali tisícileté soupeření svých zemí s germanizačními snahami. Německo a Rakousko-Uhersko označovali za nejméně demokratické země Evropy a oba zdůrazňovali, že Rakousko již svou identitu ztratilo a musí proto zaniknout. V aktualizujícím kontextu poté Masaryk a Dmowski ve snaze odůvodnit nutnost vzniku československého a polského státu pro evropskou rovnováhu poukazovali na skutečnost, že jejich národy dokázaly v dobách, kdy byli dostatečně silné a nezávislé, německé expanzi na východ účinně čelit.

Podobná byla Masarykova a Dmowského koncepce poválečné střední Evropy počítající se vznikem nezávislých států v prostoru mezi Německem a Ruskem. Tato koncepce se v Masarykově i Dmowského př́ípadě zakládala v argumentačním ohledu na varování před pangermanismem a německými projekty Mitteleuropy a vyslovovala hypotézu, podle které za předpokladu, že Německo (a jím de facto kontrolované Rakousko) ovládne středovýchodní Evropu, získá př́istup ke klíčovým materiálním zdrojům, v přriští válce mu v realizaci jeho cílů nezabrání již nikdo a bude následně moci dobýt i celý svět. Masaryk i Dmowski přitom požadovali úplnou porážku Německa s vojenským obsazením německého území a vstupem spojeneckých vojsk do Berlína (k čemuž nedošlo).

Masaryk i Dmowski byli přesvědčeni o specifickém postavení svých národů v rámci v rámci slovanské části Evropy. Pojetí této specifičnosti se však v Masarykově a Dmowského zachycení podstatně lišilo - Masaryk spatřoval českou (československou) specifičnost v kulturní rovině, Dmowski v tradici národní politiky. Masaryk připisoval českému teritoriu specifické postavení země nejvíce předsunuté na západ, což z českých zemí v Masarykově interpretaci nečinilo okraj slovenského světa, nýbrž spíše předvoj, zemi, kde bylo slovanství poprvé (dříve než v Rusku) vědecky a teoreticky formulováno. Dmowski se domníval, že Poláci byli politicky nejrozvinutějším slovanským národem, protože jako jediní Slované v průběhu dějin rozvinuli domácí autenticky polskou civilizaci s plnou sociální strukturou. Poláci měli podle Dmowského jako jediný slovanský národ kontinuálně existující národní politickou elitu (politické elity v Rusku vznikly podle Dmowského pod cizími, zvláště německými vlivy, a ruské politické kruhy byly proto údajně civilizačně neruské). 


\section{The search for New Europe in texts of Tomáš Garrigue Masaryk and Roman Dmowski: a comparative perspective}

The article deals with comparative analysis of the search for New Europe in texts of Tomáš Garrigue Masaryk (1850-1937) and Roman Dmowski (1864-1939). Both Masaryk and Dmowski belonged to prominent representatives of public and political life in their countries at the end of the $19^{\text {th }}$ and in first decades of the $20^{\text {th }}$ centuries. Masaryk and Dmowski influenced Czech and Polish politics, political and intellectual thought before 1914. During the First World War, they became leaders of Czechoslovak and Polish politics in West European emigration (Masaryk as the president of the Czechoslovak National Committee, Dmowski as the president of the Polish National Committee). The goal of their efforts consisted in re-establishment of the independent Czechoslovak and Polish state. In the course of the war, both Masaryk and Dmowski elaborated projects of New Europe. On the basis of historical examples and geographical (geopolitical) arguments, their projects attempted to justify the independent existence of postwar Czechoslovakia and Poland and intended to demonstrate why the reconstruction of the European political map is a necessity for international balance of power. Nevertheless, in the postwar period, their career diverged. Masaryk became president of Czechoslovakia and symbol of the Czechoslovak identity, Dmowski represented rather the opposition against mainstream development in postwar Poland. Last but not least, in consequence of it, Masaryk's postwar optimistic and democratic vision of New Europe contrasted with Dmowski's reflections on the crisis of European and Western civilization, scepticism about democracy and propensity for authoritarian ideologies. 